\title{
Revealing the Profile of Student Concept Understanding in the Covid-19 Pandemic Era with a Five-tier Format Assessment
}

\author{
Doni Setiawan*, Jaelani Jaelani \\ Department of Electrical Engineering, Politeknik Muhammadiyah Tegal, Indonesia \\ *Corresponding author. Email: donisukisno@gmail.com
}

\begin{abstract}
This study aims to reveal the profile of students' conceptual understanding in the era of the covid-19 pandemic using a five-tier format of assessment using electricity and magnetism. This type of research is a qualitative descriptive research. This study used a sample of students majoring in engineering at the Politeknik Muhammadiyah Tegal. Questionnaires, online diagnostic tests, and online interviews were employed to collect data. The results of the data analysis revealed that the profile of students' conceptual knowledge revealed that 30.5 percent of students grasped the concept, while 36.3 percent did not, $3.1 \%$ false positive, $2.4 \%$ false negative, and $27.7 \%$ misconception. There are 41 types of student misconceptions identified. The concepts of dynamic electricity and electric circuits include a number of common misconceptions. students believe that electric current is difficult to flow in a large wire because the thickness of the wire blocks electric current. This conception is caused by the factors of reading books and teaching materials, the learning process during school and lectures, intuition in life, as well as logic and basic knowledge possessed by students.
\end{abstract}

Keywords: Five-Tier Diagnostic Assessment, Concept Understanding, Covid-19 pandemic

\section{INTRODUCTION}

The Covid-19 pandemic that occurred had an impact on various sectors of life covering various fields, namely social, economic, cultural, tourism and education. This pandemic has prevented schools from carrying out face-to-face learning activities as usual. If the learning technique has been concentrated on faceto-face learning with a variety of approaches, such as demonstrations, discussions, project-based and problem-solving-based learning, and so on, then the learning process at all levels, It will be automatically moved from primary to higher education.

The online learning system is in the form of distance education implementation with the aim of increasing equitable access to quality learning. Learning can also be interpreted as learning organized by educational institutions where students and teachers are in different places, As a result, an interactive telecommunication system connecting student and teacher communication is necessary. pupils and professors, as well as the mechanisms by which they communicate with one another [1].

Today, the online learning model has been widely accepted by students because it is considered that this model makes students more relaxed and less tense, more fun, more flexible, efficient, effective, practical, fast, precise, safe, easy, time-saving, energy-saving. With the online learning model, it can make it easier to gather in the same place without having to travel to that place.

Another benefit of online learning models is that it is easier for parents to supervise their children because the learning process is carried out at home so that it can be directly supervised by parents. Online learning makes students and parents more able to learn and be able to operate and master technology, which is not necessarily possible in the pre-pandemic era. Online 
learning also accelerates the realization of the 5.0 era, and increases the creativity of students [2].

Online learning is used at all stages of education, from elementary to post-secondary. Learning in higher education is expected to be more prepared in preparing the online learning process, both from students and lecturers, However, professors report that there are a number of issues that make online learning challenging to execute. Students find it challenging to comprehend the lecturer's notions when they are learning online. This certainly affects students' conceptions, where one of the things that influences student conceptions is the learning process [3].

It is vital to identify student misunderstandings since the efficacy of the learning process is tied to their identification. Identification of student conceptions at the beginning of learning is used to detect student misconceptions, so that misconceptions can be remedied so that learning objectives can be achieved. A diagnostic test is one of the most effective techniques to detect student misconceptions. The use of the misconceptions diagnostic test can be done as a pretest or posttest [4].

A diagnostic test is one of the most effective techniques to detect student misconceptions. Multiple choice diagnostic tests are considered more effective and efficient in detecting student misconceptions because they can be processed using a computerized system [5]. For misconceptions, there are various different sorts of multiple-choice diagnostic exams.. The simplest form is a two-tier diagnostic test. The questions and response alternatives make up the first tier of this diagnostic test, while the justification for the answers makes up the second. The two-tier diagnostic test was then upgraded to a three-tier diagnostic test that included a confidence index for the answers as well as a statement of reasoning. By providing the confidence index in the response and the explanation for the answer, the three-tier diagnostic test was rebuilt into a four-tier diagnostic exam [6].

The four-tier diagnostic test comprises four levels of questions: multiple choice, level of confidence in the answers, reason for the statement of answers, confidence index of the reasons for the answers, and belief in the correlation between the answers and the reasons for the answers. [7].
In the preliminary study, the researcher found that sometimes students believed in the truth of the answers and the reasons for the answers, However, they were unsure if there was a link between the answers and the reasons for the answers, therefore confidence in the link between the answers and the reasons for the answers had to be added in the fifth layer. Based on these reasons, a five-tier format diagnostic test was developed to reveal the profile of students' understanding of electrical concepts in the era of the covid-19 pandemic.

\section{METHOD}

This research is divided into two stages, namely the stage of developing a five-level diagnostic assessment and the stage of revealing the profile of students' conceptual understanding. This study was carried out in Tegal. The research population is all engineering students in the city of Tegal. The students in this study are politeknik Muhammadiyah Tegal engineering majors. The variables in this study are the validity, reliability, and feasibility of the instrument, as well as the concept understanding profile of the Politeknik Muhammadiyah Tegal engineering students. The development procedure follows Sugiyono's development steps procedure namely: (1) The stage of seeing potentials and problems, (2) The stage of collecting information and literature study, (3) The stage of designing and compiling the product, (4) The stage of product validation, (5) The stage of revising the product, (6) The stage conduct product trials, (7) The stage of revising the products that have been tested, (8) The stage of testing the use of products that have been revised. The process for determining students' conceptual knowledge consists of the following steps : (1). Concept understanding test using a five-tier format assessment, (2) Analysis of test answers with interpretation guidelines, (3) mapping the categories of student concept understanding.

The expert validation test was carried out by two lecturers of the engineering department, Politeknik Muhammadiyah Tegal. Expert validation is used to assess the items in terms of the suitability of the material, the construction of the questions, and the grammar used. A 4-scale Likert scale approach was used to create the expert validation questionnaire. The results of expert validation are then used to guide the improvement of the assessment to then carry out a 
readability test and a large-scale test. The readability test was conducted on 15 engineering students, Politeknik Muhammadiyah Tegal. The readability test was used to assess the instrument from the aspect of sentence readability, ease of understanding sentences, readability of figures and tables, and the suitability of the time of questioning with the number of questions. The results of the readability test are used as a guide for improving the assessment to be tested on a large scale. At Politeknik Muhammadiyah Tegal, a largescale test was conducted on 38 engineering students. Construct validity and instrument reliability tests make up the large-scale test. Construct validity test using SPSS software. The validity test uses the moment product correlation formula, according to [8] in the following equation.

where:

$r_{\mathrm{xy}}=$ Correlation coefficient between variables $\mathrm{X}$ and Y

$\mathrm{N}=$ Number of subjects

$\mathrm{X}=$ Score for each item

$\mathrm{Y}=$ Correct total score of each subject

$\mathrm{r}_{\mathrm{xy}}=\frac{N \Sigma X Y-(\Sigma X)(\Sigma Y)}{\sqrt{\left\{N \Sigma X^{2}-(\Sigma X)^{2}\right\}\left\{N \Sigma Y^{2}-(\Sigma Y)^{2}\right\}}}$

The item items are declared valid if $r_{x y}>r_{\text {table. [8] }}$. The instrument reliability test uses the Cronbach alpha formula according to [8] with the help of SPSS software. If $r_{\text {count }}>0.600$, the instrument is considered dependable. The student's concept understanding test was carried out by mapping the results of online test answers using google form media against the interpretation guidelines according to [9] which were developed from the results of [6]. Students' understanding of concepts is then mapped and classified into concept understanding, not understanding concepts, misconceptions, false positives, and false negatives. Table 1 shows decisionmaking guidelines for student concepts.

Table 1. Guidelines for decision making on student concepts

\begin{tabular}{|l|l|}
\hline Answer combination & Criteria \\
\hline $\begin{array}{l}\text { The correct answer, the } \\
\text { correct reason, the second }\end{array}$ & Understand \\
Concept \\
\hline
\end{tabular}

\begin{tabular}{|c|c|}
\hline $\begin{array}{l}\text { and fourth tier Certainty of } \\
\text { response index (CRI) values } \\
\text { are more than } 2.5 \text {, and think } \\
\text { there's a link between the } \\
\text { answers and the reasons for } \\
\text { them }\end{array}$ & \\
\hline $\begin{array}{l}\text { Wrong answer, wrong reason, } \\
\text { second and fourth tier } \\
\text { Certainty of response index } \\
\text { (CRI) values are less than } 2.5 \\
\text { and believe there is a } \\
\text { correlation between answers } \\
\text { and reasons. }\end{array}$ & Misconception \\
\hline $\begin{array}{l}\text { Correct answer, CRI value }> \\
2.5 \text { and the reason is wrong, } \\
\mathrm{CRI} \text { value }>2.5 \text { and believe } \\
\text { that there is a correlation } \\
\text { between answers and } \\
\text { reasons. }\end{array}$ & $\begin{array}{l}\text { False positive, } \\
\text { which is a } \\
\text { condition where } \\
\text { there are rarely } \\
\text { indications of } \\
\text { misconceptions }\end{array}$ \\
\hline $\begin{array}{l}\text { Wrong answer, CRI value }> \\
2.5 \text { and the reason is correct, } \\
\mathrm{CRI} \text { value }>2.5 \text { and believe } \\
\text { that there is a correlation } \\
\text { between answers and } \\
\text { reasons }\end{array}$ & $\begin{array}{l}\text { False negative, } \\
\text { which is a situation } \\
\text { where } \\
\text { misconceptions } \\
\text { are often indicated }\end{array}$ \\
\hline
\end{tabular}

In the category of not understanding the concept, the principles of decision making are presented in Table 2.

Table 2. Principles of decision-making based on the criteria of not grasping the concept

\begin{tabular}{|l|c|c|l|}
\hline $\begin{array}{l}\text { CRI } \\
\text { tier 2 }\end{array}$ & $\begin{array}{l}\text { CRI } \\
\text { tier 4 }\end{array}$ & $\begin{array}{l}\text { Correlation } \\
\text { of answers } \\
\text { and reasons }\end{array}$ & Criteria \\
\hline$>2,5$ & $>2,5$ & $>2,5$ & $\begin{array}{l}\text { Another from } \\
\text { not } \\
\text { understanding } \\
\text { the concept }\end{array}$ \\
\hline$>2,5$ & $>2,5$ & $<2,5$ & \multirow{2}{*}{$\begin{array}{l}\text { Don't } \\
\text { understand the } \\
\text { concept }\end{array}$} \\
\hline$>2,5$ & $<2,5$ & $>2,5$ & \\
\hline$<2,5$ & $>2,5$ & $>2,5$ & \\
\hline$>2,5$ & $<2,5$ & $<2,5$ & \\
\hline$<2,5$ & $>2,5$ & $<2,5$ & \\
\hline$<2,5$ & $<2,5$ & $>2,5$ & \\
\hline$<2,5$ & $<2,5$ & $<2,5$ & \\
\hline
\end{tabular}

The percentage of each category of student knowledge after mapping the categories of student understanding of concepts with interpretation rules. The number of students who experience misconceptions is then categorized by percentage according to [10] as presented in Table 3, where $\mathrm{M}$ is the number of pupils who have misconceptions and is expressed as a percentage. 
Table 3. Categories of student misconceptions

\begin{tabular}{|c|c|}
\hline $\begin{array}{c}\text { Number of } \\
\text { Misconceptions }\end{array}$ & Criteria \\
\hline $0 \leq \mathrm{M}<30 \%$ & Low \\
\hline $30 \% \leq \mathrm{M}<60 \%$ & Medium \\
\hline $60 \% \leq \mathrm{M}<100 \%$ & High \\
\hline
\end{tabular}

\section{DISCUSSION}

The assessment developed consists of five-tier format diagnostic instruments and answer interpretation guidelines. The five-tier format diagnostic assessment developed consists of the first tier, namely multiple-choice conceptual questions with four answer choices, the second tier, namely the CRI value against the first tier, the third tier, namely the answer reasons with four choices of reasons, and the fourth tier, which compares the CRI value to the third. third, and the fifth tier is CRI to the correlation of the first and third tiers.

The results of the expert validation test by two engineering lecturers at the Politeknik Muhammadiyah Tegal on the five-tier formatted assessment showed that the assessment could be used with a few revisions. With a description: the suitability of the material with the learning objectives is quite good, the construction of the questions is good, and the grammar used is correct and easy to understand. The readability test was carried out on 15 engineering students at the Politeknik Muhammadiyah Tegal. The results of the readability test showed that the readability of the sentences in the assessment was good, the language was clear and easy to understand, The format of the phrases was consistent, and the graphics and tables were simple to comprehend. The large-scale test includes construct validity and instrument reliability testing. The subjects in the construct validity test were 38 engineering students at the Politeknik Muhammadiyah Tegal. Test the validity of the moment product correlation formula according to Pearson in [8]. The results of the construct validity test were obtained from 21 questions, 15 questions were declared valid. In line with the research results of [11] that the results of the test of the validity of the multilevel diagnostic assessment items obtained a high value of item validity.

The evaluation was declared credible after a reliability test using Cronbach's Alpha formula yielded $r_{\text {count }}=0.921 .$. In line with the research results of [9] that the multilevel diagnostic assessment reliability test can use the Cronbach Alpha formula.

The findings of the combined analysis of student responses and answer interpretation guidelines, it was found that the understanding of the concepts of students majoring in engineering at the Politeknik Muhammadiyah Tegal was grouped into understanding concepts, misconceptions, false positives, and false negatives are all examples of things that are not fully understood. The percentage of students that understand each category is depicted in Figure 1.

\section{Profile of Student Concept Understanding}

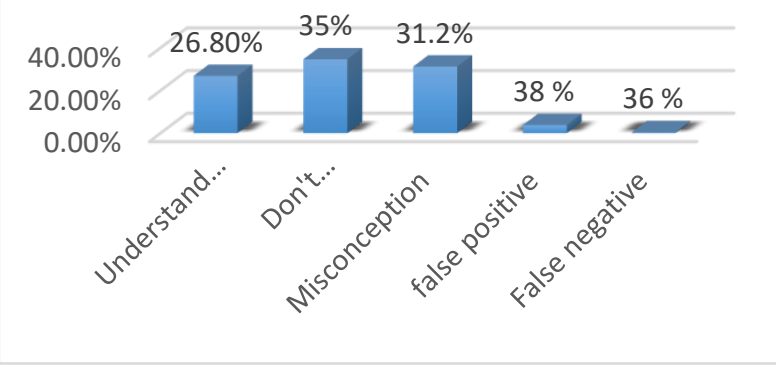

Figure 1 Profile of Student Concept Understanding

The number of students experiencing misconceptions is categorized as moderate, understanding concepts is categorized as low, not understanding concepts is categorized as moderate, Because the risk of a false positive is minimal, the risk of a false negative is also low. This is in line with [9], who claims that pupils frequently have electrical misconceptions. Table 4 indicates the percentage of pupils who fully understand everything. The biggest misconception is found in the subject of dynamic electricity with a percentage of $38.4 \%$. The other biggest misconception is found in the subject of electrical circuits with a percentage of $36.4 \%$.

Table 4. Percentage of student understanding

\begin{tabular}{|l|l|l|l|l|l|}
\hline Subject & \multicolumn{4}{|c|}{ Concept understanding (\%) } \\
\cline { 2 - 6 } & $\begin{array}{l}\text { Under } \\
\text { stand }\end{array}$ & $\begin{array}{l}\text { Do not } \\
\text { under } \\
\text { stand }\end{array}$ & $\begin{array}{l}\text { false } \\
\text { posit } \\
\text { ive }\end{array}$ & $\begin{array}{l}\text { False } \\
\text { negati } \\
\text { ve }\end{array}$ & $\begin{array}{l}\text { Miscon } \\
\text { ception }\end{array}$ \\
\hline
\end{tabular}




\begin{tabular}{|c|c|c|c|c|c|c|c|c|c|c|c|}
\hline $\begin{array}{l}\text { Static } \\
\text { electricity }\end{array}$ & 24.6 & 40.2 & 2.6 & 3.9 & 22.2 & $\begin{array}{l}\text { Average } \\
(\%)\end{array}$ & 26.8 & 35 & 3.8 & 3.6 & 31.2 \\
\hline $\begin{array}{l}\text { Dynamic } \\
\text { electricity }\end{array}$ & 34.3 & 20.0 & 4.7 & 2.6 & 38.4 & \multirow{4}{*}{\multicolumn{6}{|c|}{$\begin{array}{l}\text { Students understand the most concepts on the } \\
\text { subject of dynamic electricity with a percentage of } \\
34.3 \% \text {. The dominant misconception finding is that } \\
\text { students believe that electric current is difficult to flow } \\
\text { in a large wire because the thickness of the wire blocks } \\
\text { lectric current. This is in line with [9] that the findings } \\
\text { of the biggest misconceptions are in the sub-concept } \\
\text { of electric power, Simple electrical circuits, electric } \\
\text { current strength, and resistance circuit configuration } \\
\text { Table } 5 \text { summarizes the findings of the student } \\
\text { misconceptions study. }\end{array}$}} \\
\hline $\begin{array}{l}\text { Alternatin } \\
\mathrm{g} \text { electric } \\
\text { current }\end{array}$ & 30.8 & 42.6 & 1.6 & 1.8 & 23.2 & & & & & & \\
\hline $\begin{array}{l}\text { Electrical } \\
\text { circuits }\end{array}$ & 27.1 & 32.6 & 2.6 & 1.3 & 36.4 & & & & & & \\
\hline $\begin{array}{l}\text { Electrom } \\
\text { agnetic } \\
\text { Induction }\end{array}$ & 29.7 & 46.1 & 3.8 & 2.2 & 18.2 & & & & & & \\
\hline
\end{tabular}

Table 5. Various Misconceptions of Engineering Students

\begin{tabular}{|c|c|}
\hline Subject & Student Misconception \\
\hline \multirow{7}{*}{ Static electricity } & $\begin{array}{l}\text { A plastic ruler rubbed with hair causes the ruler to have a positive charge and silk cloth rubbed } \\
\text { with glass makes the silk positively charged. }\end{array}$ \\
\hline & $\begin{array}{l}\text { Two objects with the same charge have the same total amount of charge so that the two objects } \\
\text { repel. }\end{array}$ \\
\hline & $\begin{array}{l}\text { The head and leaves of the electroscope become positively charged when it is brought close } \\
\text { to a positively charged object. }\end{array}$ \\
\hline & $\begin{array}{l}\text { The head and leaves of the electroscope become negatively charged when it is brought close } \\
\text { to a negatively charged object. }\end{array}$ \\
\hline & $\begin{array}{l}\text { The electrons in the electroscope move irregularly in all directions when brought near a } \\
\text { positively charged object }\end{array}$ \\
\hline & $\begin{array}{l}\text { When a negatively charged object is introduced close to the electroscope's head, the } \\
\text { electroscope's head vibrates negatively, and the electroscope's leaves become positively } \\
\text { charged. }\end{array}$ \\
\hline & The movement of electrons is in the direction of high potential to low potential \\
\hline \multirow{17}{*}{ Dynamic electricity } & $\begin{array}{l}\text { The size of the voltage source determines the quantity of electric current flowing in a branched } \\
\text { circuit }\end{array}$ \\
\hline & The flow of electricity is in the direction of low potential to high potential. \\
\hline & $\begin{array}{l}\text { The magnitude of an electric current at a given location is determined by the distance between } \\
\text { that location and the voltage source. }\end{array}$ \\
\hline & In a parallel circuit, the sum of the electric currents leaving the junctions is zero.. \\
\hline & The electric power is proportional to the size of the wire. \\
\hline & $\begin{array}{l}\text { Electric current is difficult to flow in a large wire because the thickness of the wire blocks the } \\
\text { electric current }\end{array}$ \\
\hline & $\begin{array}{l}\text { Each point in the series resistance circuit has the same magnitude of electric voltage as the } \\
\text { source voltage. }\end{array}$ \\
\hline & The electric current flowing in a parallel circuit is always the same \\
\hline & The point closest to the voltage source has the greatest potential difference. \\
\hline & The more resistors in the circuit, the greater the total voltage \\
\hline & Electrical power is only affected by the source voltage \\
\hline & The voltage and the resistance are inversely related to the magnitude of the electric current. \\
\hline & The magnitude of the electric current is proportional to the voltage and the resistor. \\
\hline & $\begin{array}{l}\text { The electrical resistance in a parallel circuit is the sum of the values of all the resistors in the } \\
\text { conductor. }\end{array}$ \\
\hline & The square of the voltage and electric current is related to the amount of electric power. \\
\hline & The square of the conductor's current and voltage determines the quantity of electric power \\
\hline & Electric power per unit time is related to the amount of electrical energy. \\
\hline
\end{tabular}




\begin{tabular}{|c|c|}
\hline Subject & Student Misconception \\
\hline & $\begin{array}{l}\text { The square of the voltage is inversely proportional to the electric current, which is proportional } \\
\text { to the electric power. }\end{array}$ \\
\hline & $\begin{array}{l}\text { Electric current is proportional to electric voltage and inversely proportional to electric voltage } \\
\text { squared. }\end{array}$ \\
\hline & Alternating current dissipation power is calculated by the average electric current \\
\hline & The average value is given by the alternating electric current measurement equipment. \\
\hline & $\begin{array}{l}\text { Voltage and electric current are vector quantities because they can be expressed in the form } \\
\text { of a phasor diagram }\end{array}$ \\
\hline \multirow{7}{*}{$\begin{array}{l}\text { Alternating electric } \\
\text { current }\end{array}$} & $\begin{array}{l}\text { A capacitor's capacitive reactance is proportional to the frequency of the alternating current } \\
\text { passing through it. }\end{array}$ \\
\hline & $\begin{array}{l}\text { The frequency of the alternating current that travels through the inductor is inversely } \\
\text { proportional to the amount of the inductive reactance of the inductor. }\end{array}$ \\
\hline & In an $R L$ circuit the voltage lags behind the amperage \\
\hline & In a series RLS circuit, the value of the electric current for each circuit is different \\
\hline & $\begin{array}{l}\text { The value of the electrical resistance in a circuit varies depending on the value of the electric } \\
\text { voltage. }\end{array}$ \\
\hline & Electrical energy is the magnitude of the electric voltage across the conductor per unit time \\
\hline & Electrical energy is the amount of electric current in a conductor per unit time \\
\hline \multirow{4}{*}{ Electrical circuits } & The LED light depends on the distance to the voltage source \\
\hline & $\begin{array}{l}\text { The direction of the magnetic lines of force in the coil and the direction of the wire winding in } \\
\text { the coil are both factors that influence the size of the induced emf. }\end{array}$ \\
\hline & $\begin{array}{l}\text { Induction emf can be generated when the magnet is outside the coil so that the number of } \\
\text { magnetic lines of force surrounding the coil is reduced }\end{array}$ \\
\hline & $\begin{array}{l}\text { Induction emf can be generated when the magnet is inside the coil so that the number of } \\
\text { magnetic lines of force surrounding the coil remains constant }\end{array}$ \\
\hline $\begin{array}{l}\text { Electromagnetic } \\
\text { Induction }\end{array}$ & The number of transformer secondary coils determines the transformer input voltage. \\
\hline
\end{tabular}

The results of interviews with ten research subjects chosen at random from a purposive sample, with the criteria of experiencing the most misconceptions, it was found that their conceptions were obtained from reading books and teaching materials, learning processes during school and lectures, intuition in their lives, as well as logic and knowledge/concepts. In line with [12] that the factors that cause student conceptions are: intuition of daily life, the process of teaching and learning activities, reading textbooks, separate collections of knowledge, specific theoretical frameworks and appreciation of initial conceptions. Another similar research was conducted by [13] that students' conceptions can be influenced when reading textbooks, both printed and electronic, and in the learning process.

\section{CONCLUSION}

The following is a five-tier diagnostic examination of misconceptions: The first tier consists of multiple-choice conceptual questions; the second tier is CRI for the first tier; the third tier consists of the explanation for the response; the fourth tier is CRI for the third tier; and the fifth tier is CRI on the correlation of the first and third tiers. The answer interpretation guide uses a combination of truth values between the answers and the reasons for the answers to the CRI, the correlation between the truth values and the correlation between the two. The assessment developed is valid, reliable and feasible to use based on expert validation tests, readability tests, construct validity tests, and reliability tests. The profile of pupils' conceptual knowledge, with 30.5 percent comprehending the concept and 36.3 percent not understanding the concept, false positive $3.1 \%$, false negative $2.4 \%$, and misconceptions $27.7 \%$. The idea of dynamic electricity and electric circuits is where the majority of the misconceptions are found. The most dominant misconception is the student's assumption that electric current is difficult to flow in a large wire because the thickness of the wire blocks the electric current. The causes of student misconceptions are reading books and teaching materials, the learning process during school and lectures, intuition in their lives, as well as logic and basic knowledge/concepts possessed

\section{ACKNOWLEDGMENTS}

Thank you to the Directorate of Research and Community Service, the Director General of Research and Development Strengthening, and the Ministry of Research, Technology, and Higher Education for supporting the Beginner Lecturer Research (PDP) in 2020/2021 with the title "Revealing the Profile of Student 
Concept Understanding in the Covid-19 Pandemic Era with a Five-tier Format Assessment. Thanks also to LLDIKTI Region VI Central Java. We also thank the LPPM Muhammadiyah Polytechnic of Tegal for guiding us in writing the PDP proposal.

\section{REFERENCES}

[1] Sevima. 2018. Indonesian Online Learning System. MillennialsLecture.https://sevima.com/learning-

[2] Napaswati, Analysis of Physics Science Learning with Online Methods in the Midst of the COVID-19 Outbreak (Case Study of MTS DDI Seppange Students, Bone Regency). Journal of Physics Education and Its Applications, 2020, pp.6-12. DOI: https://doi.org/10.1007/978-3-540-72522-0_6

[3] S. Linuwih,Alternative Conceptions of Physics Students on Thermodynamic Materials. UPEJ (Unnes Physics Education Journal), 2013, 2(3). https://doi.org/10.15294/upej.v2i3.2929

[4] H.Pesman, Development of a Three-Tier Test to Assess Misconceptions About Simple Electric Circuits, The Journal of Education Research, 2010, pp. 208-222, DOI: 10.1080/00220670903383002

[5] F. Türker, Developing a Three-tier Test to Asses High School Students' Misconceptions Concerning Force and Motion, Tesis, Middle East Technical University, 2015, pp. 220-227.

[6] D.K.Gurel, D, A. Eryilmaz, L,C McDermott, A Review and Comparison of Diagnostic Instruments to Identify Students' Misconceptions in Science. Eurasia Journal of Mathematics, Science, \& Technology Education, 2015 11(5), pp. 989-1008. doi:10.12973/eurasia.2015.1369a

[7] U. Turgut, An Investigation 10th grade students misconceptions about electric current Procedia Social and behavioral Sciences, 2011, pp. 19651971

[8] S. Arikunto, Dasar-Dasar Evaluasi Pendidikan, Jakarta : Bumi Aksara, 2010, pp. 51-63

[9] D. Setiawan, N. Faoziyah, Development of a FiveTier Diagnostic Test to Reveal the Student Concept in Fluids, Physics Communication, 2019, pp. 6-13

[10] T.E.Rabiudin, Mursalin, Development of Authentic Affective Assessment Instrument in High School Physics Learning Development of Authentic Affective Assessment Instrument in High School Physics Learning, Journal of Physics, Conf.Serie, 2018, pp. 6-8

[11] A. Samsudin, E. Suhendi, I.I. Ismail, Diagnostics of Misconceptions Through Dynamic Electricity Four Tier Test, (Snips), 2015, pp. 381-384.
[12] S. Linuwih, Alternative Conceptions of Physics Students on Thermodynamic Materials. UPEJ (Unnes Physics Education Journal), 2013, pp. 6-9. https://doi.org/10.15294/upej.v2i3.2929

[13] I. Caleon, R. Subramaniam, Development and Application of a Three-tier Diagnostic Test to Asses Secondary Students' Understanding of Waves. International Journal of Science Education, 2010, pp. 939-961 